\title{
PEMBUATAN KECAP ASIN KORO PEDANG (Canavalia ensiformis L.) YANG DIPENGARUHI PERBANDINGAN TEMPE KORO PEDANG DENGAN TEMPE AMPAS TAHU DAN KONSENTRASI LARUTAN GARAM
}

\author{
Tantan Widiantara \\ Hasnelly \\ Risma Listia Deviana \begin{abstract}
Indonesia
E-mail : tantanwidiantara@unpas.ac.id
\end{abstract} \\ Program Studi Teknologi Pangan, Fakultas Teknik, Universitas Pasundan, J1. Dr.Setiabudi No 93, Bandung, 40153,
}

\begin{abstract}
Abstrak
Tujuan penelitian ini adalah untuk memperoleh proporsi antara kacang kedelai tempe dan tahu ampas tahu dan konsentrasi larutan garam yang memberikan pengaruh terbaik terhadap kualitas saus. Manfaat dari penelitian ini adalah untuk memberikan informasi tentang proporsi yang tepat antara kacang kedelai dan ampas tahu serta konsentrasi larutan garam yang tepat dalam membuat saus kacang kedelai. Selain itu, penelitian ini juga diharapkan dapat memperkaya jenis diversifikasi bahan baku dalam pembuatan kecap sehingga dapat meningkatkan nilai ekonomi bahan tersebut. Metode penelitian primer menggunakan rancangan acak lengkap dengan faktorial $3 \times 3$ dan diulang sebanyak tiga kali. Faktor pertama adalah proporsi kacang kedelai tempe dan ampas tahu tempe (k) terdiri dari tiga taraf yaitu k1 (1:1), k2 (2: 1) dan k3 (1: 2). Faktor kedua adalah konsentrasi larutan garam (g) terdiri dari tiga level yaitu g1 (15\%), g2 (20\%) dan g3 (25\%). Analisis dari penelitian ini adalah analisis kimia (protein dan kadar garam), analisis fisik (viskositas) dan uji organoleptik (warna, rasa dan rasa) menggunakan metode duo-trio. Hasil penelitian menunjukkan bahwa proporsi kacang kedelai tempe dan ampas tahu tempe, konsentrasi larutan garam dan interaksi mereka memberikan pengaruh yang signifikan terhadap semua respon. Perlakuan terbaik dari penelitian ini adalah k2g3 (proporsi tempe kacang kedelai dan ampas tahu tempe adalah 2: 1 dan konsentrasi larutan garam adalah 25\%) yang terdiri dari $17,71 \%$ kandungan protein, 22,50\% kadar garam dan viskositasnya adalah 12 m.Pas.
\end{abstract}

\begin{abstract}
The purpose of the research was to obtain a proportion between jack bean tempeh and tofu dregs tempeh and concentration of salt solution that gave the best influence to the quality of the sauce. The benefits of this research was to provide information about the proper proportion between jack bean and tofu dregs as well as the proper concentration of salt solution in making jack bean sauce. The method of primary research used completely randomized design with $3 \times 3$ factorial and repeated for three times. The first factor was a proportion of jack bean tempeh and tofu dregs tempeh (k) consist of three levels that was k1 (1:1), k2 (2:1) and k3 (1:2). The second factor was concentration of the salt solution (g) consist of three levels that was g1 (15\%), g2 (20\%) and g3 (25\%). The analysis of this research were chemical analysis (protein and salt levels), physical analysis (viscosity) and organoleptic test (the color, flavour and taste) used duo-trio method. The result of the research showed that the proportion of jack bean tempeh and tofu dregs tempeh, concentration of the salt solution and their interaction gave significant effect to all responses. The best treatment of this research was $\mathrm{k} 2 \mathrm{~g} 3$ (proportion of jack bean tempeh and tofu dregs tempe was $2: 1$ and the concentration of the salt solution was $25 \%$ ) which consist of $17.71 \%$ protein content, $22.50 \%$ salt content and its viscousity was 12 m.Pas.
\end{abstract}

Keywords: soy sauce, fermentation, jack beans, tofu-dregs and salt concentration.

\section{Pendahuluan}

Kecap merupakan salah satu produk tradisional yang banyak dikonsumsi masyarakat sebagai penyedap cita rasa makanan. Pembuatan kecap berasal dari negara Cina berabad-abad tahun silam, kemudian diperkenalkan ke Jepang dan negara Asia lainnya. Produk kecap ini dikenal dengan nama Chiang-Yu di Cina, Shoyu di Jepang, Kanjang di Korea, Toyo di Filipina, dan See-Tew di Thailand (Irman, 2002).
Di Indonesia kecap dikenal sebagai penyedap makanan karena dapat memberikan rasa dan aroma yang khas pada makanan atau masakan. Secara umum, kecap merupakan produk olahan atau awetan kedelai dengan tekstur cair (asin) dan kental (manis), berwarna cokelat kehitaman, dan digunakan sebagai penyedap masakan (Turyoni, 2007).

Selama ini kecap lebih umum terbuat dari kacang kedelai atau berbahan baku ikan. Harga kacang kedelai 
yang tinggi menjadi salah satu masalah dalam hal produksi kecap, sehingga dibutuhkan bahan alternatif sebagai pengganti kacang kedelai. Indonesia membutuhkan kedelai sekitar 2,0 juta ton pada tahun 2007. Sementara produksi kedelai dalam negeri hanya mampu memenuhi sekitar antara 600-700 ribu ton dari kebutuhan Nasional, hal ini didasarkan keterangan dari Departemen Pertanian (2008). Kekurangan produksi tersebut, pemerintah telah import kedelai dari Negara lain, terutama dari Amerika Serikat sebesar 1,3 juta ton untuk tahun 2007. Maka perlu digali potensi komoditas yang dapat menjadi pengganti atau substansi kedelai. Salah satu alternatifnya adalah kacang koro yang sudah dikenal masyarakat (Sofyan, 2009 dalam Nurul, 2012).

Proses pembuatan kecap yang terpenting adalah bahan baku yang mengandung protein cukup tinggi, untuk mengatasi masalah ketersediaan bahan baku alternatif dan guna mendukung program diversifikasi sumber pangan bergizi, maka potensi kacang-kacangan relatif besar karena kandungan protein cukup tinggi, pengadaannya mudah dan relatif murah harganya dibandingkan dengan sumber protein hewani (daging, telur, maupun susu). Salah satu jenis kacang-kacangan yang dijadikan sumber bahan baku pembuatan kecap ini adalah kacang koro pedang (Irman, 2002).

Kacang koro pedang mempunyai potensi yang sangat besar apabila ditinjau dari segi gizi dan syarat tumbuhnya, dari kandungan gizinya, koro memiliki semua unsur gizi dengan nilai gizi yang cukup tinggi. Kandungan nutrisi pada kacang koro relatif berimbang dengan kacang kedelai, dengan demikian protein kacang koro dapat dimanfaatkan secara optimal menjadi bahan pangan yang bergizi.

Salah satu bahan yang dapat dimanfaatkan sebagai bahan alternatif pembuatan kecap adalah ampas tahu. Pemanfaatan ampas tahu menjadi kecap dilakukan dengan beberapa pertimbangan. Pertama, kontinuitas ketersediannya cukup terjamin. Kedua, ampas tahu masih mengandung protein sekitar 5\% (Sarwono, 2005), sehingga dapat dimanfaatkan sebagai produk yang dapat menjadi sumber protein.

Prinsipnya proses pembuatan kecap melalui dua tahapan fermentasi yaitu fermentasi kapang dan fermentasi garam. Selama proses fermentasi baik fermentasi kapang maupun fermentasi garam akan terjadi perubahan-perubahan secara fisik maupun kimiawi karena aktivitas dari mikroba tersebut. Selama fermentasi kapang, kapang yang berperan akan memproduksi enzim seperti enzim amilase, enzim protease, dan enzim lipase. Dengan adanya kapang tersebut maka akan terjadi pemecahan komponenkomponen dari bahan tersebut. Selama proses fermentasi garam, enzim-enzim hasil dari fermentasi kapang akan memecah komponen-komponen gizi dari kedelai menjadi senyawa-senyawa yang lebih sederhana (Sumanti, 2010 dalam Atuti, 2011).
Perpaduan kacang koro pedang dengan ampas tahu dalam pembuatan kecap akan menjadi hal baru yang diharapkan bisa menjawab persoalan yang dimiliki produsen kecap selama ini, yaitu dengan menggunakan bahan baku yang potensinya belum diketahui dapat menghasilkan produk kecap berkualitas yang sama seperti kecap kedelai.

Maksud dari penelitian ini adalah untuk memanfaatkan ampas tahu dalam pembuatan kecap asin koro pedang. Tujuan dari penelitian ini adalah untuk memperoleh perbandingan tempe koro pedang dengan ampas tahu yang memberikan pengaruh paling baik terhadap mutu kecap yang dihasilkan serta konsentrasi larutan garam yang paling tepat.

Menurut SNI (1999), kecap kedelai adalah produk cair yang diperoleh dari hasil fermentasi dan atau cara kimia (hidrolisis) kacang kedelai dengan atau tanpa penambahan bahan makanan lain dan bahan tambahan makanan yang diizinkan.

Proses fermentasi kecap terdiri dari dua tahap, yaitu fermentasi kapang (solid state fermentation) dan fermentasi moromi dalam larutan garam (brine fermentation) (Koswara, 1997 dalam Rianty, 2014).

Proses fermentasi kecap terdiri dari dua tahap, yaitu fermentasi kapang (solid state fermentation) dan fermentasi moromi dalam larutan garam (brine fermentation) (Koswara, 1997 dalam Rianty, 2014).

Kapang yang berperan dalam fermentasi kecap, antara lain Aspergillus orizae, A. niger, dan Rhizopus $s p$. Hasil fermentasi kapang dapat disebut koji atau tempe (Astawan, 1991 dalam Rianty, 2014).

Lama inkubasi memberikan pengaruh terhadap kualitas tempe kacang gude dinilai dari kandungan protein, lemak dan karbohidrat. Kandungan protein akan meningkat seiring bertambahnya waktu inkubasi, nilai tertinggi terdapat pada tempe yang diinkubasi selama 48 jam (Sayuti, 2015).

Menurut Sarwono (2005) ampas tahu masih memiliki kadar protein 5\%. Namun demikian untuk meningkatkan kualitas kecap maka dapat dilakukan upaya dengan penambahan bahan baku lain yang termasuk dalam sumber protein. Jadi bahan baku pembuatan kecap dilakukan dengan melakukan kombinasi bahan lain yang difermentasi yang bertujuan untuk meningkatkan kadar protein hasil akhir.

Menurut Yuantita (2013) dalam pembuatan kecap asin ampas tahu dari perhitungan menggunakan multiple attributte, diperoleh bahwa sampel a3t2 (ampas tahu 300 gr dan koro benguk 100 gr) dan a3t3 (ampas tahu 300 gr dan koro benguk 200 gr) merupakan sampel terbaik. Dengan penambahan kacang koro benguk nilai protein pada kecap ampas tahu dapat ditingkatkan.

Penambahan garam pada kecap umumnya adalah 20\%-23\%. Adapun biasanya digunakan konsentrasi garam 17\%-19\% (Hidayah, 2014). 
Menurut Halimah (1996) dalam Irman (2002), bahwa penggunaan jamur Aspergillus orizae dengan lama fermentasi selama $0-1$ bulan pada proses pembuatan kecap lebih baik dibandingkan dengan lama fermentasi 2-4 bulan. Dimana hal ini disebabkan, bahwa pada lama waktu fermentasi 0-1 bulan zat-zat yang terkandung dalam kacang kedelai mengalami peningkatan dibandingkan dengan waktu lama fermentasi 2-4 bulan.

Berdasarkan kerangka pemikiran tersebut maka didapatkan hipotesis sebagai berikut:

1. Perbandingan tempe koro pedang dengan tempe ampas tahu berpengaruh terhadap karakteristik kecap yang dihasilkan.

2. Konsentrasi larutan garam berpengaruh terhadap karakteristik kecap yang dihasilkan.

3. Interaksi antara perbandingan tempe koro pedang dengan tempe ampas tahu dan konsentrasi larutan garam berpengaruh terhadap karakteristik kecap yang dihasilkan.

\section{Bahan dan Metodologi Penelitian}

Bahan baku utama yang digunakan dalam penelitian ini adalah kacang koro pedang (Canavalia ensiformis L.) yang didapatkan dari Majalaya dan ampas tahu yang didapatkan dari pabrik pengolahan tahu di Lembang. Bahan baku penunjang yang digunakan adalah garam, air, "ragi tempe" atau kapang Rhizopus sp, Cassava Powder dan bumbu-bumbu seperti bawang putih, ketumbar, pekak, kunyit, daun salam, sereh, lengkuas, keluak, gula merah dan vetsin.

Bahan analisis yang digunakan untuk analisis produk meliputi, garam kjedahl $\mathrm{Na}_{2} \mathrm{SO}_{4}, \mathrm{H}_{2} \mathrm{SO}_{4}$ pekat, batu didih, aquadest, $\mathrm{NaOH} 30 \%, \mathrm{Na}_{2} \mathrm{~S}_{2} \mathrm{O}_{3} 5 \%$, larutan baku $\mathrm{NaOH} 0,1 \mathrm{~N}$, granul $\mathrm{Zn}$, dan $\mathrm{HCl} 0,1 \mathrm{~N}$.

Penelitian pendahuluan dilakukan untuk menentukan lama fermentasi koji pada kacang koro pedang dan ampas tahu sehingga menjadi produk tempe sebagai bahan baku kecap untuk penelitian utama. Fermentasi dilakukan dengan beberapa variasi waktu, setelah itu dilakukan pengujian organoleptik untuk menentukan perlakuan terbaik. Penelitian pendahuluan dalam penelitian ini dilakukan dalam dua tahap percobaan yaitu:

1. Penentuan Lama Fermentasi Koji Kacang Koro Pedang

Penelitian pendahuluan yang akan dilakukan yaitu untuk menentukan lama fermentasi koji kacang koro pedang sehingga menjadi produk tempe koro pedang. Lama fermentasi koji tersebut dilakukan 1 hari, 2 hari, dan 3 hari. Tempe koro pedang yang diperoleh kemudian dilakukan uji organoleptik oleh 15 orang panelis dan tempe koro pedang yang paling banyak dipilih menurut tingkat mutu hedonik panelis akan dijadikan acuan dalam penelitian utama. Respon uji organoleptik terhadap tempe koro pedang yaitu warna, aroma dan tekstur.
2. Penentuan Lama Fermentasi Koji Ampas Tahu

Penelitian pendahuluan yang akan dilakukan yaitu untuk menentukan lama fermentasi koji ampas tahu sehingga menjadi produk tempe ampas tahu. Lama fermentasi koji tersebut dilakukan 2 hari, 3 hari dan 4 hari. Tempe ampas tahu yang diperoleh kemudian dilakukan uji organoleptik oleh 15 orang panelis dan tempe ampas tahu yang paling banyak dipilih menurut tingkat mutu hedonik panelis akan dijadikan acuan dalam penelitian utama. Respon uji organoleptik terhadap tempe koro pedang yaitu warna, aroma, dan tekstur.

Penelitian utama dilakukan untuk menentukan pengaruh perbandingan tempe koro pedang dengan tempe ampas tahu, pengaruh konsentrasi larutan garam dan pengaruh interaksi dari keduanya.

\section{Rancangan Percobaan}

Rancangan perlakuan terdiri dari dua faktor yaitu perbandingan tempe koro pedang dengan tempe ampas tahu $(\mathrm{K})$ terdiri atas 3 taraf dan konsentrasi larutan garam (G) terdiri atas 3 taraf, dengan urutan sebagai berikut:

Faktor Perbandingan Tempe Koro Pedang dengan Ampas Tahu (K), terdiri dari 3 taraf yaitu:

$\mathrm{k}_{1}=$ Perbandingan Tempe Koro Pedang dan Tempe Ampas tahu (1:1)

$\mathrm{k}_{2}=$ Perbandingan Tempe Koro Pedang dan Tempe Ampas tahu (2:1)

$\mathrm{k}_{3}=$ Perbandingan Tempe Koro Pedang dan Tempe Ampas tahu (1:2)

Faktor Konsentrasi Larutan Garam $(\mathrm{G})$, terdiri dari 3 taraf yaitu:

$\mathrm{g}_{1}=$ Konsentrasi Larutan Garam $15 \%$

$\mathrm{g}_{2}=$ Konsentrasi Larutan Garam $20 \%$

$\mathrm{g}_{3}=$ Konsentrasi Larutan Garam $25 \%$

\section{Rancangan Analisis}

Percobaan diulang 3 kali sehingga percobaan terdiri atas $3 \times 3 \times 3=27$ satuan percobaan.

Tabel 1. Model Eksperimen Interaksi Pola Faktorial (3x3) dalam Rancangan Acak Kelompok dengan 3 kali Ulangan

\begin{tabular}{|c|c|c|c|c|}
\hline \multirow{2}{*}{$(\mathrm{K})$} & \multirow{2}{*}{$(\mathrm{G})$} & \multicolumn{3}{|c|}{ Kelompok Ulangan } \\
\cline { 3 - 5 } & & $\mathrm{I}$ & $\mathrm{II}$ & $\mathrm{III}$ \\
\hline \multirow{3}{*}{$\mathrm{k}_{1}(1: 1)$} & $15 \%\left(\mathrm{~g}_{1}\right)$ & $\mathrm{k}_{1} \mathrm{~g}_{1}$ & $\mathrm{k}_{1} \mathrm{~g}_{1}$ & $\mathrm{k}_{1} \mathrm{~g}_{1}$ \\
\cline { 2 - 5 } & $20 \%\left(\mathrm{~g}_{2}\right)$ & $\mathrm{k}_{1} \mathrm{~g}_{2}$ & $\mathrm{k}_{1} \mathrm{~g}_{2}$ & $\mathrm{k}_{1} \mathrm{~g}_{2}$ \\
\cline { 2 - 5 } & $25 \%\left(\mathrm{~g}_{3}\right)$ & $\mathrm{k}_{1} \mathrm{~g}_{3}$ & $\mathrm{k}_{1} \mathrm{~g}_{3}$ & $\mathrm{k}_{1} \mathrm{~g}_{3}$ \\
\hline \multirow{3}{*}{$\mathrm{k}_{2}(2: 1)$} & $15 \%\left(\mathrm{~g}_{1}\right)$ & $\mathrm{k}_{2} \mathrm{~g}_{1}$ & $\mathrm{k}_{2} \mathrm{~g}_{1}$ & $\mathrm{k}_{2} \mathrm{~g}_{1}$ \\
\cline { 2 - 5 } & $20 \%\left(\mathrm{~g}_{2}\right)$ & $\mathrm{k}_{2} \mathrm{~g}_{2}$ & $\mathrm{k}_{2} \mathrm{~g}_{2}$ & $\mathrm{k}_{2} \mathrm{~g}_{2}$ \\
\cline { 2 - 5 } & $25 \%\left(\mathrm{~g}_{3}\right)$ & $\mathrm{k}_{2} \mathrm{~g}_{3}$ & $\mathrm{k}_{2} \mathrm{~g}_{3}$ & $\mathrm{k}_{2} \mathrm{~g}_{3}$ \\
\hline \multirow{3}{*}{$\mathrm{k}_{3}(1: 2)$} & $15 \%\left(\mathrm{~g}_{1}\right)$ & $\mathrm{k}_{3} \mathrm{~g}_{1}$ & $\mathrm{k}_{3} \mathrm{~g}_{1}$ & $\mathrm{k}_{3} \mathrm{~g}_{1}$ \\
\cline { 2 - 5 } & $20 \%\left(\mathrm{~g}_{2}\right)$ & $\mathrm{k}_{3} \mathrm{~g}_{2}$ & $\mathrm{k}_{3} \mathrm{~g}_{2}$ & $\mathrm{k}_{3} \mathrm{~g}_{2}$ \\
\cline { 2 - 5 } & $25 \%\left(\mathrm{~g}_{3}\right)$ & $\mathrm{k}_{3} \mathrm{~g}_{3}$ & $\mathrm{k}_{3} \mathrm{~g}_{3}$ & $\mathrm{k}_{3} \mathrm{~g}_{3}$ \\
\hline
\end{tabular}




\section{Rancangan Respon}

Analisis produk akhir yang dilakukan terhadap kecap koro pedang meliputi respons kimia, respons fisika, dan organoleptik.

\section{A. Respon Kimia}

Respon kimia yang akan dilakukan terhadap kecap asin koro pedang meliputi: analisis kadar protein dengan metode Kjedhal dan analisis kadar garam dengan menggunakan alat Saltinitymeter.

B. Respon Fisika

Respon fisika yang akan dilakukan terhadap kecap asin koro pedang yaitu: uji viskositas menggunakan alat viskometer.

C. Respon Organoleptik

Respon organoleptik yang akan dilakukan terhadap kecap koro pedang yaitu: uji Duo-Trio terhadap warna, aroma dan rasa oleh 20 panelis.

\section{Rancangan Penentuan Perlakuan Terpilih}

Penentuan perlakuan terpilih berdasarkan pada rata-rata hasil dari respon kimia (kadar protein dan kadar garam), respon fisika (viskositas), dan respon organoleptik Duo-Trio. Nilai rata-rata tersebut dibandingkan kesesuaianya dengan nilai yang tercantum pada SNI (Standar Nasional Indonesia) terutama untuk respon kimia dan fisika, sedangkan untuk respon organoleptik Duo-Trio dilihat dari kesesuaian nilai rata-rata yang diberikan oleh panelis dan dibandingkan dengan nilai pada tabel Two Sample Test yang menunjukkan ada tidaknya perbedaan dengan sampel baku. Sampel yang dipilih pada DuoTrio adalah sampel yang memiliki perbedaan yang sangat kecil. Setelah sampel dibandingkan dan memiliki kesesuaian dengan SNI maupun organoleptik, kemudian diambil satu sampel terbaik yaitu yang memiliki nilai rata-rata terbesar dari kandungan proteinnya.

\section{Hasil dan Pembahasan}

Penelitian pendahuluan dilakukan untuk menentukan lama waktu fermentasi koji terbaik pada kacang koro pedang dan ampas tahu untuk menjadi produk tempe. Variasi waktu fermentasi untuk kacang koro pedang yaitu 1 hari, 2 hari, dan 3 hari. Variasi waktu fermentasi untuk ampas tahu yaitu 2 hari, 3 hari, dan 4 hari. Penelitian pendahuluan dilakukan dengan menggunakan uji organoleptik metode mutu hedonik terhadap warna, aroma dan tekstur.

\section{Respon Organoleptik Tempe Koro Pedang}

Hasil analisis variansi (ANAVA) terhadap tempe koro pedang menunjukan bahwa perlakuan lama fermentasi berpengaruh nyata terhadap warna, aroma dan tekstur tempe koro pedang, sehingga dilakukan uji lanjut Duncan untuk mengetahui perbedaan pengaruhnya. Hasil uji organoleptik tempe koro pedang terhadap warna, aroma dan tekstur dapat dilihat pada Tabel 3.
Tabel 3. Hasil Organoleptik Tempe Koro Pedang

\begin{tabular}{|c|c|c|c|c|c|c|}
\hline Perlakuan & \multicolumn{2}{|c|}{ Warna } & \multicolumn{2}{|c|}{ Aroma } & \multicolumn{2}{|c|}{ Tekstur } \\
\hline $\begin{array}{c}\text { Lama } \\
\text { fermentasi 1 } \\
\text { hari (1 } 1 \text { ) }\end{array}$ & 3,41 & a & 2,82 & a & 2,88 & a \\
\hline $\begin{array}{c}\text { Lama } \\
\text { fermentasi 2 } \\
\left.\text { hari (1 } 1_{2}\right)\end{array}$ & $\mathbf{5 , 0 5}$ & $\mathbf{c}$ & $\mathbf{4 , 5 6}$ & $\mathbf{c}$ & $\mathbf{5 , 1 6}$ & $\mathbf{c}$ \\
\hline $\begin{array}{c}\text { Lama } \\
\text { fermentasi 3 } \\
\text { hari }\left(1_{3}\right)\end{array}$ & 3,61 & b & 3,59 & b & 3,69 & b \\
\hline
\end{tabular}

Hasil data statistik pada Tabel 8. menunjukkan bahwa perlakuan lama fermentasi terbaik adalah selama 2 hari. Semakin lama waktu fermentasi menunjukkan peningkatan warna, aroma dan tekstur yang nyata pada $l_{1}$ terhadap $l_{2}$ dan $l_{3}$, sedangkan $l_{2}$ terhadap $l_{3}$ terjadi penurunan warna yang signifikan.

\section{Respon Organoleptik Tempe Ampas Tahu}

Hasil analisis variansi (ANAVA) terhadap tempe ampas tahu menunjukan bahwa perlakuan lama fermentasi berpengaruh nyata terhadap warna, aroma dan tekstur tempe ampas tahu, sehingga dilakukan uji lanjut Duncan untuk mengetahui perbedaan pengaruhnya. Hasil uji organoleptik tempe ampas tahu terhadap warna, aroma dan tekstur dapat dilihat pada Tabel 4.

Tabel 4. Hasil Organoleptik Tempe Ampas Tahu

\begin{tabular}{|c|c|c|c|c|c|c|}
\hline Perlakuan & \multicolumn{2}{|c|}{ Warna } & \multicolumn{2}{c|}{ Aroma } & \multicolumn{2}{|c|}{ Tekstur } \\
\hline $\begin{array}{c}\text { Lama } \\
\text { fermentasi 2 } \\
\left.\text { hari ( } \mathrm{t}_{1}\right)\end{array}$ & $\mathbf{4 , 1 5}$ & $\mathbf{b}$ & $\mathbf{3 , 6 0}$ & $\mathbf{b}$ & $\mathbf{4 , 0 5}$ & $\mathbf{c}$ \\
\hline $\begin{array}{c}\text { Lama } \\
\text { fermentasi 3 } \\
\left.\text { hari ( } \mathrm{t}_{2}\right)\end{array}$ & 3,21 & $\mathrm{a}$ & 2,78 & $\mathrm{a}$ & 3,20 & $\mathrm{~b}$ \\
\hline $\begin{array}{c}\text { Lama } \\
\text { fermentasi } 4 \\
\left.\text { hari ( } \mathrm{t}_{3}\right)\end{array}$ & 3,10 & $\mathrm{a}$ & 2,78 & $\mathrm{a}$ & 2,96 & $\mathrm{a}$ \\
\hline
\end{tabular}

Hasil data statistik pada Tabel 9. menunjukkan bahwa perlakuan lama fermentasi terbaik adalah selama 2 hari. Semakin lama waktu fermentasi menunjukkan penurunan warna, aroma dan tekstur yang nyata pada $t_{1}$ terhadap $t_{2}$ dan $t_{3}$.

a. Warna

Hasil data pada Tabel 8 dan 9 diketahui, bahwa tempe koro pedang dan tempe ampas tahu dengan lama fermentasi 2 hari memiliki rata-rata nilai warna yaitu 5,05 dan 4,15 dapat diartikan bahwa mutu hedonik terhadap warna tempe koro pedang dan tempe ampas tahu yaitu putih keabuan dan agak putih keabuan.

Tempe mempunyai ciri-ciri warna putih atau putih keabuan. Warna putih ini disebabkan adanya miselia kapang yang tumbuh pada permukaan biji 
kedelai. Tempe segar adalah tempe yang berwarna putih dengan jamur yang banyak dan tebal. Sebenarnya tempe yang mengandung banyak spora adalah tempe yang tua (hampir busuk), namun kondisinya tidak memungkinkan untuk dikeringkan dan disimpan. Tempe segar tidak dapat disimpan lama karena paling lama kuat disimpan 2x24 jam, lewat masa itu kapang tempe mati dan selanjutnya akan tumbuh bakteri atau mikroba perombak protein akibatnya tempe cepat busuk (Sarwono, 2005).

b. Aroma

Hasil data pada Tabel 8 dan 9 diketahui, bahwa tempe koro pedang dan tempe ampas tahu dengan lama fermentasi 2 hari memiliki rata-rata nilai aroma yaitu 4,56 dan 3,60 dapat diartikan bahwa mutu hedonik terhadap aroma tempe koro pedang dan tempe ampas tahu yaitu khas tempe dan agak khas tempe.

Aroma dan rasa khas tempe terbentuk karena terjadinya degradasi komponen-komponen dalam tempe selama berlangsungnya proses fermentasi. Tempe segar mempunyai aroma lembut seperti jamur yang berasal dari aroma miselium kapang bercampur dengan aroma lezat dari asam amino bebas dan aroma yang ditimbulkan karena penguraian lemak makin lama fermentasi berlangsung, aroma yang lembut berubah menjadi tajam karena terjadi pelepasan amonia (Astawan, 2004).

Aroma yang dinilai adalah rangsangan yang dihasilkan oleh tempe koro pedang maupun tempe ampas tahu yang diketahui oleh indera pembau. Indera pembau adalah instrumen yang paling banyak berperan mengetahui aroma terhadap makanan. Dalam industri makanan pengujian terhadap bau dianggap sangat penting karena dengan cepat dapat memberikan hasil penelitian terhadap produk. Dalam pengujian inderawi, bau lebih komplek daripada rasa. Bau atau aroma akan mempercepat timbulnya rangsangan kelenjar air liur (Kartika, 1998).

c. Tekstur

Hasil data pada Tabel 8 dan 9 diketahui, bahwa tempe koro pedang dan tempe ampas tahu dengan lama fermentasi 2 hari memiliki rata-rata nilai tekstur yaitu 5,16 dan 4,05 dapat diartikan bahwa mutu hedonik terhadap tekstur tempe koro pedang dan tempe ampas tahu yaitu kompak dan agak kompak.

Kekompakan tekstur tempe disebabkan oleh miselia-miselia kapang yang menghubungkan antara biji-biji kedelai. Kompak tidaknya tekstur tempe dapat diketahui dengan melihat lebat tidaknya miselia yang tumbuh pada permukaan tempe. Apabila miselia tampak lebat, hal ini menunjukkan bahwa tekstur tempe telah membentuk masa yang kompak, begitu juga sebaliknya (Kasmidjo, 1990 dalam Astuti, 2009).

Tempe merupakan produk hasil proses fermentasi dengan waktu 36-48 jam. Hal ini ditandai dengan pertumbuhan kapang yang hampir tetap dan tekstur lebih kompak. Jika proses fermentasi terlalu lama menyebabkan terjadinya kenaikan jumlah bakteri, jumlah asam lemak bebas, pertumbuhan jamur juga menurun, dan menyebabkan degradasi protein lanjut sehingga terbentuk amoniak. Akibatnya tempe yang dihasilkan mengalami proses pembusukan dan aromanya menjadi tidak enak.

Tempe dengan kualitas buruk ditandai dengan permukaannya yang basah, struktur tidak kompak, adanya bercak bercak hitam, adanya bau amoniak dan alkohol, serta beracun (Astawan, 2004 dalam Astuti, 2009).

\section{Penentuan Perlakuan Terpilih pada Penelitian Pendahuluan}

Hasil pengujian yang dilakukan dengan uji organoleptik metode mutu hedonik, pemilihan produk atau sampel dengan perlakuan terbaik menurut panelis terhadap warna, aroma dan tekstur tempe koro pedang dan tempe ampas tahu adalah perlakuan tempe koro pedang dan tempe ampas tahu dengan lama waktu fermentasi 2 hari, hal ini dapat terlihat dari kriteria nilai yang tinggi pada waktu fermentasi selama 2 hari. Hasil dari penelitian pendahuluan ini selanjutnya akan digunakan pada penelitian utama. Grafik uji organoleptik mutu hedonik terhadap warna, aroma dan tekstur tempe koro pedang dan tempe ampas tahu dapat dilihat pada Gambar 1 dan 2.

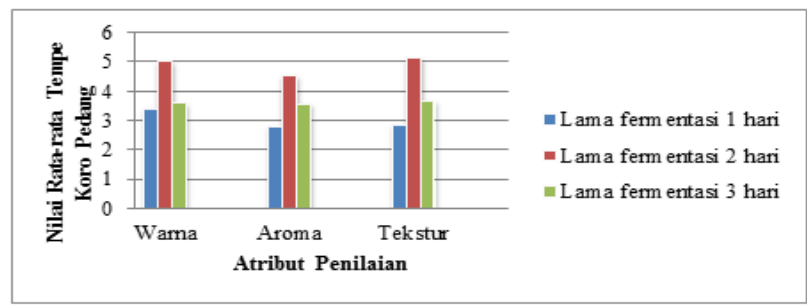

Gambar 1. Grafik Hasil Organoleptik Tempe Kacang Koro Pedang.

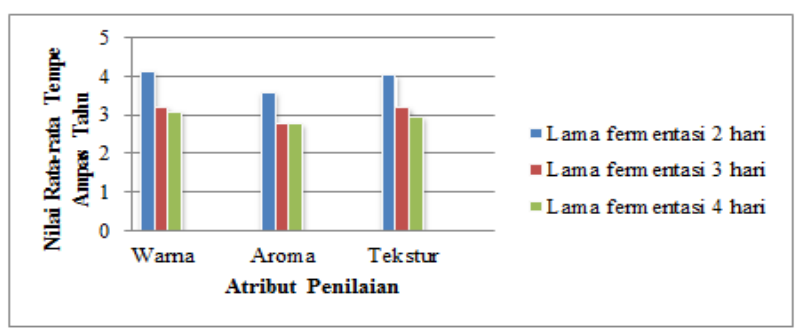

Gambar 2. Grafik Hasil Organoleptik Tempe Ampas Tahu.

\section{Respon Kimia \\ Kadar Protein}

Protein merupakan suatu zat makanan yang amat penting bagi tubuh karena zat ini disamping berfungsi sebagai bahan bakar dalam tubuh juga berfungsi sebagai zat pembangun dan pengatur. 
Hasil analisis variansi (ANAVA) terhadap kecap koro pedang menunjukan bahwa perbandingan tempe koro pedang dengan tempe ampas tahu $(\mathrm{K})$, konsentrasi larutan garam (G) dan interaksi keduanya berpengaruh nyata terhadap kadar protein kecap koro pedang (Canavalia ensiformis), sehingga dilakukan uji lanjut Duncan untuk mengetahui perbedaan pengaruhnya. Pengaruh interaksi tempe koro pedang dengan tempe ampas tahu $(\mathrm{K})$ dan konsentrasi larutan garam (G) dapat dilihat pada Tabel 5.

Tabel 5. Pengaruh Interaksi Perbandingan Tempe Koro Pedang dengan Tempe Ampas Tahu (K) dan Konsentrasi Larutan Garam (G) terhadap Kadar Protein Kecap

\begin{tabular}{|c|c|c|c|}
\hline \multirow{2}{*}{$\begin{array}{c}\text { Perbandingan Tempe Koro Pedang } \\
\text { dengan Tempe Ampas Tahu } \\
\text { (K) }\end{array}$} & \multicolumn{3}{|c|}{$\begin{array}{c}\text { Konsentrasi Larutan Garam } \\
\text { (G) }\end{array}$} \\
\hline & g1 $(15 \%)$ & g2 $(20 \%)$ & g3 $(25 \%)$ \\
\hline k1 (1:1) & $\begin{array}{c}3,18^{\mathrm{A}} \\
\mathrm{b}\end{array}$ & $\begin{array}{c}2,59 \\
a^{A}\end{array}$ & $\begin{array}{cc}4,02 \\
c \\
c\end{array}$ \\
\hline k2 (2:1) & $\begin{array}{cc}10,26^{\mathrm{C}} \\
\mathrm{b}\end{array}$ & $\begin{array}{c}6,33^{B} \\
a\end{array}$ & $\begin{array}{c}17,71 \\
\mathrm{c}\end{array}$ \\
\hline k3 (1:2) & $\begin{array}{c}8,14^{B} \\
b\end{array}$ & $\begin{array}{c}11,72 \\
c\end{array}$ & $\begin{array}{cc}4,89 & \text { B } \\
\text { a } & \\
\end{array}$ \\
\hline
\end{tabular}

Tabel 10. menunjukkan bahwa semakin tinggi konsentrasi larutan garam pada perbandingan tempe koro pedang dengan tempe ampas tahu yang tetap yaitu pada k1 dan k2 terjadi penurunan kadar protein yang nyata pada g1 terhadap g2 yang diikuti kenaikan kadar protein yang nyata pada g2 terhadap g3, sedangkan pada k3 terjadi penurunan kadar protein yang nyata pada g1 terhadap g2 dan $\mathrm{g} 3$.

Perbandingan tempe koro pedang dengan tempe ampas tahu pada konsentrasi larutan garam yang tetap yaitu g1, g2 dan g3 terjadi kenaikan kadar protein yang nyata pada k1 terhadap k2 dan k3, sedangkan pada g1 dan g2 diikuti penurunan kadar protein yang nyata pada $\mathrm{k} 2$ terhadap $\mathrm{k} 3$.

Interaksi antara perbandingan tempe koro pedang dengan tempe ampas tahu dan konsentrasi larutan garam memberikan pengaruh yang nyata terhadap kadar protein kecap asin koro pedang. Perlakuan k2g3 merupakan perlakuan yang menghasilkan kadar protein tertinggi pada kecap koro pedang, hal ini terjadi pada saat fermentasi moromi oleh larutan garam, enzim-enzim yang dihasilkan pada fermentasi kapang masih terus bekerja, sehingga protein kompleks yang terkandung pada bahan terus mengalami proteolisis oleh enzim protease menjadi fraksi-fraksi peptida yang lebih pendek dan asam-asam amino sehingga dapat meningkatkan kadar protein total di akhir fermentasi. Apabila konsentrasi garam terlalu tinggi akan menghambat proses fermentasi dan menyebabkan kematian mikroorganisme yang seharusnya hidup, sedangkan jika konsentrasi garam terlalu rendah bakteri asam laktat belum dapat tumbuh dan dapat mengakibatkan pembentukkan $\mathrm{pH}$ yang tidak stabil serta menyebabkan kerusakan.
Perlakuan k1g2 merupakan perlakuan dengan hasil kadar protein terendah, hal ini bisa disebabkan oleh beberapa faktor diantaranya proses fermentasi, kondisi pemasakan, seleksi kapang, perbaikan inokulasi dan inkubasi kapang (Judoamidjojo, 1987 dalam Yohana, 2011).

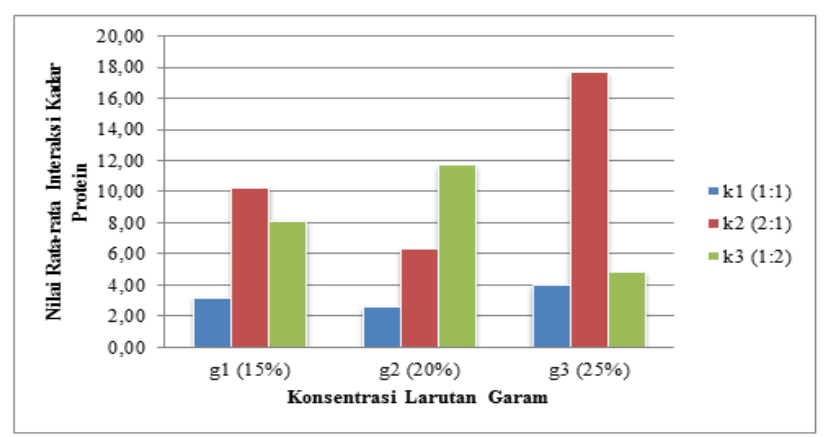

Gambar 3. Grafik Interaksi Faktor Perbandingan Tempe Koro Pedang dengan Tempe Ampas Tahu (K) dan Konsentrasi Larutan Garam (G) terhadap Kadar Protein Kecap.

Perlakuan perbandingan tempe koro pedang dengan tempe ampas tahu, konsentrasi larutan garam dan interaksinya memberikan pengaruh yang nyata terhadap kadar protein kecap koro pedang, hal ini terjadi karena jumlah kacang koro pedang dan ampas tahu yang digunakan pada setiap perlakuan berbeda, sehingga kadar protein yang dihasilkan berbeda nyata. Pada proses fermentasi dengan menggunakan konsentrasi garam tinggi, bahan pangan yang mengandung senyawa seperti protein, karbohidrat, lemak dan mineral akan memiliki konsentrasi yang tinggi pula sedangkan vitamin dan zat warna berkurang, namun dengan adanya proses pemasakan, kadar protein akan menurun (Minarso, 1980 dalam Astuti, 2011). Penambahan garam pada proses fermentasi moromi memberikan pengaruh yang nyata terhadap kandungan protein.

Sampel yang memiliki kadar protein tertinggi adalah sampel k2g3 dimana perbandingan tempe koro pedang dengan tempe ampas tahu (2:1) dan konsentrasi larutan garam 25\% menghasilkan kadar protein $17,71 \%$.

Kadar protein kecap koro pedang dalam penelitian mulai dari $2,59 \%$ sampai $17,71 \%$, hal ini menunjukkan kadar protein kecap koro pedang lebih kecil dibandingkan dengan kacang koro pedang yang berkisar $23-34 \%$, hal ini disebabkan oleh perendaman dan perlakuan panas. Kecap koro pedang dilakukan pemasakan, pada proses pemasakan akan terjadi reaksi Maillard yang mengakibatkan penurunan nilai gizi (Rahayu, 1992 dalam Astuti, 2011). Penurunan nilai gizi protein dikarenakan terjadinya reaksi Maillard yang diakibatkan oleh lisin dan sistein yang mengalami kerusakan karena bereaksi dengan senyawa karbonil atau dikarbonil dengan aldehid dan diakibatkan 
terbentuknya ikatan silang (cross linkage) antar asamasam amino sehingga terjadi penurunan ketersediaan asam-asam amino serta penurunan daya cerna karena terhambatnya penetrasi enzim kedalam substrat protein atau karena tertutupnya sisi protein yang dapat diserang enzim (Winarno, 1992).

Penurunan kadar protein disebabkan pula karena adanya fermentasi kapang. Kapang Rhizopus Oligosporus bersifat proteolitik dan kapang ini penting dalam pemutusan protein. Kapang ini akan mendegradasi protein selama proses fermentasi menjadi peptida dan seterusnya menjadi $\mathrm{NH}_{3}$ atau $\mathrm{N}_{2}$ yang hilang melalui penguapan (Hasseltine, 1965 dalam Astuti, 2011).

\section{Kadar Garam}

Garam dipergunakan manusia sebagai salah satu metoda pengawetan pangan yang pertama dan masih dipergunakan secara luas untuk mengawetkan berbagai makanan (Buckle, 1987).

Hasil analisis variansi (ANAVA) terhadap kecap koro pedang menunjukan bahwa perbandingan tempe koro pedang dengan tempe ampas tahu (K), konsentrasi larutan garam (G) dan interaksi keduanya berpengaruh nyata terhadap kadar garam kecap koro pedang (Canavalia ensiformis), sehingga dilakukan uji lanjut Duncan untuk mengetahui perbedaan pengaruhnya. Pengaruh interaksi tempe koro pedang dengan tempe ampas tahu $(\mathrm{K})$ dan konsentrasi larutan garam (G) dapat dilihat pada Tabel 6.

Tabel 6. Pengaruh Interaksi Faktor Perbandingan Tempe Koro Pedang dengan Tempe Ampas Tahu (K) dan Konsentrasi Larutan Garam (G) terhadap Kadar Garam Kecap Koro

\begin{tabular}{|c|c|c|c|}
\hline $\begin{array}{c}\text { Perbandingan Tempe Koro Pedang } \\
\text { dengan Tempe Ampas Tahu } \\
(\mathrm{K})\end{array}$ & \multicolumn{3}{|c|}{$\begin{array}{c}\text { Konsentrasi Larutan Garam } \\
\text { (G) }\end{array}$} \\
\cline { 2 - 5 } k1 (1:1) & $\mathrm{g} 1(15 \%)$ & $\mathrm{g} 2(20 \%)$ & $\mathrm{g} 3(25 \%)$ \\
\hline $\mathrm{k} 2(2: 1)$ & $\begin{array}{c}15,25 \\
\mathrm{a}\end{array}$ & $\begin{array}{c}18,25 \\
\mathrm{~b}\end{array}$ & $\begin{array}{c}20,00 \\
\mathrm{C}\end{array}$ \\
\hline \multirow{2}{*}{$\mathrm{k} 3(1: 2)$} & $\begin{array}{c}17,50 \\
\mathrm{a}\end{array}$ & $\begin{array}{c}18,33 \\
\mathrm{~b}\end{array}$ & $\begin{array}{c}22,50 \\
\mathrm{C}\end{array}$ \\
\hline & $\begin{array}{c}14,83 \\
\mathrm{a}\end{array}$ & $\begin{array}{c}17,50 \\
\mathrm{~b}\end{array}$ & $\begin{array}{c}23,58 \\
\mathrm{C}\end{array}$ \\
\hline
\end{tabular}

Tabel 11. menunjukkan bahwa semakin tinggi konsentrasi larutan garam pada perbandingan tempe koro pedang dengan tempe ampas tahu yang tetap yaitu $\mathrm{k} 1$, k2 dan k3 terjadi kenaikan kadar garam yang nyata pada g1 terhadap g2 dan g3.

Perbandingan tempe koro pedang dengan tempe ampas tahu pada konsentrasi larutan garam yang tetap yaitu pada g1 dan g2 terjadi kenaikan yang nyata pada k1 terhadap k2, dan diikuti penurunan kadar garam yang nyata pada $\mathrm{k} 2$ terhadap $\mathrm{k} 3$, sedangkan pada g3 terjadi kenaikan kadar garam yang yang nyata pada pada $\mathrm{k} 1$ terhadap $\mathrm{k} 2$ dan $\mathrm{k} 3$.

Interaksi antara perbandingan tempe koro pedang dengan tempe ampas tahu dan konsentrasi larutan garam memberikan pengaruh yang nyata terhadap kadar garam kecap asin koro pedang. Selama proses fermentasi terjadi penurunan kadar garam $\mathrm{NaCl}$ yang disebabkan pecahnya senyawa kompleks $\mathrm{NaCl}$ menjadi ion $\mathrm{Na}^{+}$dan $\mathrm{Cl}^{-}$. Ion $\mathrm{Na}^{+}$dibutuhkan oleh bakteri asam laktat sebagai substitusi ion $\mathrm{K}^{+}$saat terjadi difusi. Ion $\mathrm{Cl}^{-}$berikatan dengan air bebas pada bahan dan menyebabkan suasana asam karena terbentuknya $\mathrm{HCl}$.

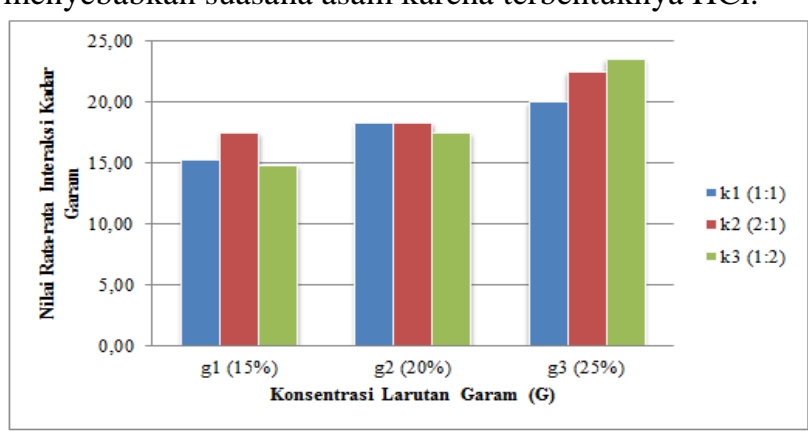

Gambar 4. Pengaruh Interaksi Faktor Perbandingan Tempe Koro Pedang dengan Tempe Ampas Tahu (K) dan Konsentrasi Larutan Garam (G) terhadap Kadar Garam Kecap Koro Pedang.

Konsentrasi larutan garam yang semakin tinggi maka kadar garam yang diserap semakin tinggi pula namun kadar air menurun. Selama proses fermentasi akan terjadi penurunan kadar air karena keseimbangan pada bahan terganggu sebagai akibat penambahan garam. Garam akan menarik air dari dalam bahan lalu masuk kedalam jaringan. Akibatnya kadar air menurun sedangkan kadar garamnya meningkat (Minarso, 1980 dalam Astuti, 2011).

Garam dalam penelitian ini sangat berperan dalam proses moromi (fermentasi garam), karena larutan garam berfungsi untuk mengeluarkan zat gizi yang terdapat dalam tempe kacang koro dan tempe ampas tahu dari proses koji. Selama proses fermentasi pertama (koji), kapang memproduksi enzim yang memecah komponen zat-zat dari kedelai, tetapi pemecahan ini belum sempurna. Berbagai jenis asam amino glutamat dan garam-garamnya yang memberi rasa khas kecap belum bisa terlarutkan dalam air. Dengan demikian fermentasi pertama harus dihentikan agar tidak menimbulkan efek samping yang merugikan, sebab bila berlanjut akan mengundang bakteri pembusuk lainnya yang tidak diinginkan. Untuk mengambil sari-sari zat dalam kacang koro dan ampas tahu sehingga dapat terlarutkan dalam air sebanyak-banyaknya, maka dilakukan fermentasi tahap kedua yang disebut fermentasi moromi. Pada tahap ini dilakukan di dalam larutan garam. Mikroorganisme yang berperan penting dalam fermentasi moromi adalah Tetragenococcus halophilus, Zhigosacharomyces rouxii dan Candida sp. Tetragenococcus halophilus merupakan bakteri asam laktat yang berperan menghasilkan asam laktat dan 
menurunkan $\mathrm{pH}$ pada awal fermentasi moromi. Setelah $\mathrm{pH}$ turun pertumbuhan Tetragenococcus halophilus akan digantikan oleh Zhigosacharomyces rouxii, yaitu khamir osmofilik yang berperan dalam fermentasi alkoholik. Pada tahap akhir fermentasi moromi, khamir halofilik Candida sp. akan tumbuh dan menghasilkan alkilfenol dan alkohol aromatik. Selalin itu Candida sp. juga akan menghasilkan komponen rasa pada kecap, yaitu 4-etilguaiacol (Judoamidjojo, et al 1989 dalam Yohana 2011).

\section{Respon Fisika}

\section{Viskositas}

Hasil analisis variansi (ANAVA) terhadap kecap koro pedang menunjukan bahwa perbandingan tempe koro pedang dengan tempe ampas tahu $(\mathrm{K})$, konsentrasi larutan garam $(\mathrm{G})$ dan interaksi keduanya berpengaruh nyata terhadap viskositas kecap koro pedang (Canavalia ensiformis), sehingga dilakukan uji lanjut Duncan untuk mengetahui perbedaan pengaruhnya. Pengaruh interaksi tempe koro pedang dengan tempe ampas tahu (K) dan konsentrasi larutan garam (G) dapat dilihat pada Tabel 7.

Tabel 7. Pengaruh Interaksi Faktor Perbandingan Tempe Koro Pedang dengan Tempe Ampas Tahu (K) dan Konsentrasi Larutan Garam (G) terhadap Viskositas Kecap.

\begin{tabular}{|c|c|c|c|}
\hline \multirow{2}{*}{$\begin{array}{l}\text { Perbandingan Tempe } \\
\text { Koro Pedang dengan } \\
\text { Tempe Ampas Tahu } \\
\text { (K) }\end{array}$} & \multicolumn{3}{|c|}{$\begin{array}{c}\text { Konsentrasi Larutan Garam } \\
\text { (G) }\end{array}$} \\
\hline & g1 $(20 \%)$ & g2 $(25 \%)$ & g3 $(25 \%)$ \\
\hline $\mathrm{k} 1(1: 1)$ & $\begin{array}{cc}6,33 \\
\mathbf{a} & \mathrm{B} \\
\end{array}$ & $\begin{array}{cc}7,00 & \text { A } \\
\text { b } & \end{array}$ & $\begin{array}{cc}16,00 \\
\mathrm{c}\end{array}$ \\
\hline k2 $(2: 1)$ & $\begin{array}{c}13,00 \\
b\end{array}$ & $\underset{\substack{14,00 \\
\mathrm{c}}}{\mathrm{B}}$ & $\begin{array}{cc}12,00 \\
a\end{array}$ \\
\hline k3 (1:2) & $\begin{array}{cc}, 00 \\
\substack{a \\
a}\end{array}$ & $\begin{array}{cc}14,00 & \text { B } \\
\mathrm{b} & \\
\end{array}$ & $\begin{array}{cc}15,33 & \text { B } \\
\text { C } & \\
\end{array}$ \\
\hline
\end{tabular}

Tabel 12. menunjukkan bahwa semakin tinggi konsentrasi larutan garam pada perbandingan tempe koro pedang dengan tempe ampas tahu yang tetap yaitu pada k1, k2 dan k3 terjadi kenaikan viskositas yang nyata pada g1 terhadap g2 dan g3, namun pada k2 diikuti penurunan viskositas yang nyata pada $\mathrm{g} 2$ terhadap g3.

Perbandingan tempe koro pedang dengan tempe ampas tahu pada konsentrasi larutan garam yang tetap yaitu pada g1 dan g2 terjadi kenaikan viskositas yang nyata pada $\mathrm{k} 1$ terhadap $\mathrm{k} 2$, dan untuk g1 diikuti penurunan yang nyata pada k2 terhadap k3. Sedangkan pada g3 terjadi penurunan viskositas yang nyata pada k1 terhadap k2 dan k3 yang diikuti kenaikan yang nyata pada $\mathrm{k} 2$ terhadap $\mathrm{k} 3$.

Interaksi antara perbandingan tempe koro pedang dengan tempe ampas tahu dan konsentrasi larutan garam memberikan pengaruh yang nyata terhadap viskositas kecap asin koro pedang. Perlakuan $\mathrm{k} 2 \mathrm{~g} 3$ merupakan perlakuan dengan hasil viskositas yang rendah namun memiliki hasil kadar protein yang tinggi, hal ini disebabkan karena berat molekul yang terkandung pada bahan, semakin besar berat molekul maka viskositasnya akan semakin tinggi begitupun sebaliknya. Perlakuan k2g3 membuktikan bahwa pada proses fermentasi terjadi pemecahan protein yang cukup sempurna yaitu dari yang memiliki berat molekul besar menjadi zat-zat yang lebih sederhana contoh zat yang memiliki bobot molekul yang rendah ialah asam-asam amino dan peptida.

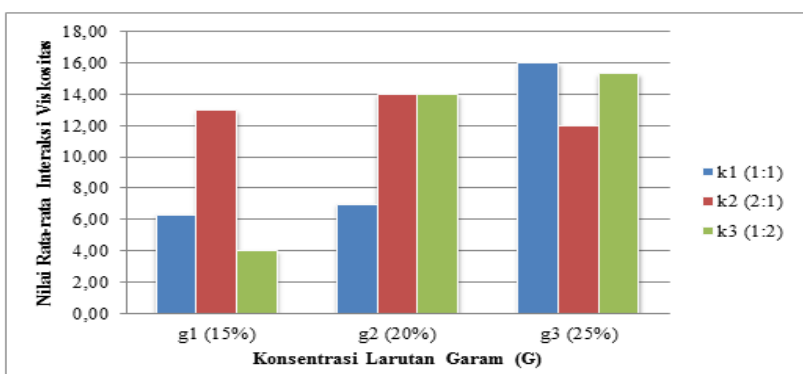

Gambar 5. Pengaruh Interaksi Faktor Perbandingan Tempe Koro Pedang dengan Tempe Ampas Tahu (K) dan Konsentrasi Larutan Garam $(\mathrm{G})$ terhadap Viskositas Kecap.

Hasil rata-rata ragam viskositas kecap asin koro pedang menunjukkan bahwa antar perlakuan memberikan pengaruh yang nyata terhadap nilai dari parameter viskositas yang dihasilkan. Menurut Kartika et al (1992) kekentalan suatu larutan dipengaruhi oleh beberapa faktor yaitu suhu, konsentrasi larutan, berat molekul (BM) dan zat terlarut. Konsentrasi garam yang digunakan pada penelitian berbeda-beda sehingga menghasilkan viskositas yang berbeda, serta berat molekul pada setiap perbandingan bahan berbeda pula.

Viskositas yang lebih tinggi juga disebabkan penurunan kadar air karena terjadinya penguapan pada saat proses fermentasi termasuk penambahan garam dan garam akan menarik air pada bahan lalu masuk kedalam jaringan sehingga kadar air pada bahan akan menurun dan jumlah padatan terlarut akan meningkat. Semakin tinggi kadar garam maka viskositas semakin tinggi.

\section{Respon Organoleptik Uji Duo-Trio}

Uji Duo-Trio merupakan salah satu uji pembeda. Uji pembeda ini biasanya digunakan untuk mengetahui ada tidaknya perbedaan antara sampel yang disajikan. Pada Duo-Trio digunakan sampel pembanding (Kartika, 1988). Uji Duo-Trio menggunakan tabel Two Sample Test sebagai pembanding jumlah respon yang benar. Taraf perbandingan yang digunakan adalah $5 \%$.

Hasil pengujian Duo-Trio terhadap warna, aroma dan rasa kecap koro pedang dapat dilihat pada Tabel 8 .

Tabel 8. Rata-rata Hasil Uji Organoleptik Duo-Trio.

\begin{tabular}{|c|c|c|c|c|}
\hline Kode & Perlakuan & Warna & Aroma & Rasa \\
\hline 110 & $\mathrm{k}_{1} \mathrm{~g}_{1}$ & $\mathbf{1 7 , 3 3}$ & 11,67 & 11,00 \\
\hline 120 & $\mathrm{k}_{1} \mathrm{~g}_{2}$ & 3,00 & 8,00 & 5,67 \\
\hline 211 & $\mathrm{k}_{1} \mathrm{~g}_{3}$ & $\mathbf{1 5 , 0 0}$ & $\mathbf{1 7 , 3 3}$ & 11,67 \\
\hline 233 & $\mathrm{k}_{2} \mathrm{~g}_{1}$ & 6,33 & 2,00 & 5,00 \\
\hline 344 & $\mathrm{k}_{2} \mathrm{~g}_{2}$ & 12,00 & 12,00 & 7,33 \\
\hline 355 & $\mathrm{k}_{2} \mathrm{~g}_{3}$ & 9,00 & 7,00 & 12,00 \\
\hline 422 & $\mathrm{k}_{3} \mathrm{~g}_{1}$ & $\mathbf{1 6 , 3 3}$ & 14,00 & 11,00 \\
\hline 411 & $\mathrm{k}_{3} \mathrm{~g}_{2}$ & 3,67 & 8,63 & 8,67 \\
\hline 577 & $\mathrm{k}_{3} \mathrm{~g}_{3}$ & 13,00 & 13,67 & 13,00 \\
\hline
\end{tabular}


Keterangan: Sampel dengan rata-rata $\geq 15$ menunjukkan perbedaan yang nyata dengan sampel baku.

Berdasarkan hasil pengamatan didapat $\Sigma$ tanggapan yang benar untuk warna dan aroma adalah 17,$33 ; 15$ dan 16,33. Sedangkan berdasarkan hasil tabel "two sample test" diperoleh $\sum$ minimum tanggapan yang benar pada taraf $5 \%$ adalah 15 sehingga dapat disimpulkan bahwa sampel k1g1 berbeda nyata dalam hal warna, sampel k1g3 berbeda nyata dalam hal warna dan aroma, dan sampel $\mathrm{k} 3 \mathrm{~g} 1$ berbeda nyata dalam hal warna Sampel tersebet berbeda nyata jika dibandingkan dengan sampel baku.

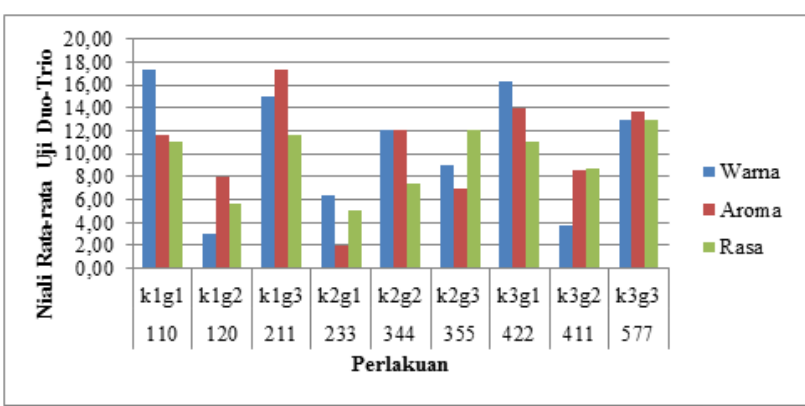

Gambar 6. Grafik Hasil Pengamatan Uji Duo-Tri

Sampel yang memiliki nilai rata-rata lebih dari atau sama dengan nilai respon pada tabel Two Sample Test menunjukkan perbedaan yang nyata dengan sampel baku. Sedangkan sampel yang memiliki nilai rata-rata kurang dari nilai respon pada tabel Two Sample Test menunjukkan bahwa sampel tersebut memiliki perbadaan yang sangat kecil, bahkan bisa dikatakan mirip dengan sample baku. Semakin kecil nilai rata-rata dari hasil pengamatan maka dapat disimpulkan sampel tersebut semakin mirip dengan sampel baku yang dibandingkan.

\section{- Warna}

Mutu bahan pangan yang umumnya sangat bergantung pada beberapa faktor diantaranya cita rasa, warna, tekstur dan nilai gizinya. Disamping itu ada faktor-faktor lain yang dipertimbangkan, secara visual faktor warna tampil lebih dahulu dan terkadang sangat menentukan. Suatu bahan yang dinilai bergizi, enak, dan teksturnya sangat baik tidak akan dimakan bila memiliki warna yang tidak sedap dipandang atau memberi kesan menyimpang dari seharusnya.warna merupakan faktor yang sangat penting untuk menilai makanan, baik makanan yang diproses maupun yang tidak diproses. Warna memegang peranan penting dalam penilaian makanan, selain bau, rasa, dan tekstur. Selain itu warna dapat memberi petunjuk mengenai perubahan kimia dalam makanan seperti pencoklatan dan pengkaramelan (Winarno, 1992).

Kelemahan uji Duo-Trio adalah berdasarkan daya ingat dari panelis terhadap atribut yang dinilai, oleh karena itu akan banyak sekali pengaruh dari human error akibat pengaruh psikologis ataupun fisiologis.
Kelebihan Duo-Trio adalah dapat mengetahui ada tidaknya perbedaan dua sampel atau mendeteksi sampel dengan tingkat perbedaan yang sangat kecil (Kartika, 1988).

\section{Penentuan Sampel Terpilih}

Berdasarkan hasil data respon kimia, fisika dan organoleptik dapat disimpulkan bahwa sampel yang memenuhi syarat adalah $\mathrm{k}_{2} \mathrm{~g}_{1}, \mathrm{k}_{2} \mathrm{~g}_{2}, \mathrm{k}_{2} \mathrm{~g}_{3}, \mathrm{k}_{3} \mathrm{~g}_{2}$ dan $\mathrm{k}_{3} \mathrm{~g}_{3}$. Sampel yang memenuhi syarat tersebut berdasarkan respon kimia dan fisika yang memiliki nilai rata-rata teringgi adalah sampel $\mathrm{k}_{2} \mathrm{~g}_{3}$. Namun dari organoleptik Duo-Trio sampel yang sangat memiliki kemiripan dengan sampel baku adalah $\mathrm{k}_{2} \mathrm{~g}_{1}$. Hal ini dikarenakan dalam hasil organoleptik sampel dibandingkan dengan sampel baku yang ada dipasaran, sampel $\mathrm{k}_{2} \mathrm{~g}_{1}$ merupakan sampel dengan konsentrasi larutan garam yang rendah, jika dibandingkan dengan produk yang ada dipasaran maka sampel tersebut akan memiliki kesamaan karena umumnya sampel yang ada dipasaran dilakukan pengenceran sehingga konsentrasi garamnya tidak terlalu tinggi. Nilai rata-rata sampel dapat dilihat pada Tabel 9 dan 10.

Tabel 9. Nilai Rata-Rata Sampel berdasarkan Respon Organoleptik.

\begin{tabular}{|c|c|c|c|c|}
\hline \multirow{2}{*}{ Perlakuan } & \multicolumn{4}{|c|}{ Organoleptik Duo-Trio } \\
\hline & Warna & Rasa & Aroma & Rata-rata \\
\hline $\mathbf{k}_{1} \mathbf{g}_{1}$ & 17,33 & 11,67 & 11 & 40 \\
\hline $\mathbf{k}_{1} \mathbf{g}_{2}$ & 3 & 8 & 5,67 & 16,67 \\
\hline $\mathbf{k}_{1} \mathbf{g}_{3}$ & 15 & 17,33 & 11,67 & 44 \\
\hline $\mathbf{k}_{2} \mathrm{~g}_{1}$ & 6,33 & 2 & 5 & 13,33 \\
\hline $\mathrm{k}_{2} \mathrm{~g}_{2}$ & 12 & 12 & 7,33 & 31,33 \\
\hline $\mathbf{k}_{2} \mathrm{~g}_{3}$ & 9 & 7 & 12 & 28 \\
\hline $\mathbf{k}_{3} \mathbf{g}_{1}$ & 16,33 & 14 & 11 & 41,33 \\
\hline$k_{3} g_{2}$ & 3,67 & 8,63 & 8,67 & 20,97 \\
\hline $\mathbf{k}_{3} \mathbf{g}_{3}$ & 13 & 13,67 & 13 & 39,67 \\
\hline
\end{tabular}

uji organoleptik. -Nilai rata-rata $\geq 15$ menunjukkan sampel berbeda nyata dengan sampel baku organoleptik.

Tabel 10. Nilai Rata-Rata Sampel berdasarkan Respon Kimia dan Fisika.

\begin{tabular}{|c|c|c|c|}
\hline \multirow{2}{*}{ Perlakuan } & \multicolumn{2}{|c|}{ Kimia } & Fisika \\
\cline { 2 - 4 } & Kadar Protein & Kadar Garam & Viskositas \\
\hline $\mathbf{k}_{\mathbf{1}} \mathbf{g}_{\mathbf{1}}$ & 3,18 & 15,25 & 6,33 \\
\hline $\mathbf{k}_{\mathbf{1}} \mathbf{g}_{\mathbf{2}}$ & 2,59 & 18,25 & 7,00 \\
\hline $\mathbf{k}_{\mathbf{1}} \mathbf{g}_{\mathbf{3}}$ & 4,02 & 20,00 & 16,00 \\
\hline $\mathbf{k}_{\mathbf{2}} \mathbf{g}_{\mathbf{1}}$ & 10,26 & 17,50 & 13,00 \\
\hline $\mathbf{k}_{\mathbf{2}} \mathbf{g}_{\mathbf{2}}$ & 6,33 & 18,33 & 14,00 \\
\hline $\mathbf{k}_{\mathbf{2}} \mathbf{g}_{\mathbf{3}}$ & 17,71 & 22,50 & 12,00 \\
\hline $\mathbf{k}_{\mathbf{3}} \mathbf{g}_{\mathbf{1}}$ & 8,14 & 14,83 & 4,00 \\
\hline $\mathbf{k}_{\mathbf{3}} \mathbf{g}_{\mathbf{2}}$ & 11,72 & 17,50 & 14,00 \\
\hline $\mathbf{k}_{\mathbf{3}} \mathbf{g}_{\mathbf{3}}$ & 4,89 & 23,58 & 15,33 \\
\hline
\end{tabular}

Keterangan: Sampel yang ditandai menunjukkan bahwa sampel tidak memenuhi syarat SNI uji kimia dan syarat uji organoleptik.

Berdasarkan Tabel. 14 dan 15 dapat ditetapkan sampel dengan perlakuan terbaik yaitu $\mathrm{k} 2 \mathrm{~g} 3$ dengan kadar protein 17,71 \%. Menurut SNI (1994), kadar protein minimal pada kecap asin yaitu $3 \%$ dan kadar 
garam minimal $10 \%$. Kadar protein merupakan parameter yang penting dalam proses pembuatan kecap. Kandungan protein yang diukur dalam penelitian ini adalah protein total, yaitu pengukuran kandungan nitrogen (N) dalam sampel. Menurut Judoamidjojo et al. (1989) dalam Yohana (2011), pada umumnya kualitas kecap dinilai dari kadar protein yang dikandungnya (total nitrogen). Walaupun preferensi konsumen lebih dominan terhadap flavor kecap, kandungan nitrogen tetap merupakan hal mendasar dalam standar kualitas. Semakin tinggi kandungan nitrogen pada kecap, semakin banyak asam amino yang terkandung juga dalam kecap tersebut. Salah satu asam amino tersebut ialah asam glutamat yang dapat menimbulkan rasa sedap. Dengan demikian, semakin banyak asam glutamat yang terkandung dalam kecap, semakin sedap (enak) kecap tersebut sehingga semakin banyak konsumen yang menyukai kecap tersebut. Menurut Standar Industri Indonesia No. 32 Tahun 1974 syarat kualitas kecap ialah berdasarkan kadar protein yang dikandungnya, dimana kecap asin mutu I kadar protein minimal sebesar $6 \%$, kecap asin mutu II kadar protein minimal sebesar 4-6\%, dan kecap asin mutu III kadar protein minimal sebesar 2-4\% (Nugrahaeni, 2008).

Berdasarkan penelitian pendahuluan uji mutu hedonik, didapatkan perlakuan lama fermentasi terbaik untuk tempe koro pedang dan tempe ampas tahu adalah 2 hari. Perbandingan tempe koro pedang dengan tempe ampas tahu berpengaruh terhadap kadar protein, kadar garam, viskositas, dan organoleptik. Konsentrasi larutan garam berpengaruh terhadap kadar protein, kadar garam, viskositas, dan organoleptik. Interaksi antara perbandingan tempe koro pedang dengan tempe ampas tahu dan kosentrasi larutan garam berpengaruh terhadap respon kimia, respon fisika, dan respon organoleptik.

Berdasarkan respon kimia, fisika dan organoleptik didapat sampel terbaik yaitu $\mathrm{k}_{2} \mathrm{~g}_{3}$ dimana perbandingan tempe koro pedang dengan tempe ampas tahu (2:1) dan konsentrasi larutan garam 25\% menghasilkan kadar protein sebesar $17,71 \%$, kadar garam 22,50\% dan viskositas 12 m.Pas.

\section{Daftar Pustaka}

1. Astawan, M. (2004). Tetap Sehat dengan Produk Makanan Olahan. Tiga Serangkai. Solo.

2. Astuti, NP. (2009). Sifat Organoleptik Tempe Kedelai yang Dibungkus Plasti, Daun Pisang dan Daun Jati. Fakultas Ilmu Kesehatan. UMS. Surakarta.

3. Astuti, JA., Sofyan, I., Suliasih, N., (2011). Pengaruh Konsentrasi Garam (NaCL) dan Lama Fermentasi terhadap Karakteristik Tauco Kacang Koro Pedang. Skripsi Jurusan Teknologi Pangan, UNPAS. Bandung.
4. Buckle,K. A. (1987). Ilmu Pangan. Penerbit Universitas Indonesia, Jakarta.

5. Hidayah, E. (2014). Pembuatan Kecap Asin Dari Koro Benguk (Macuna pruriens). Jurusan Teknologi Hasil Pertanian FTP UB. Malang.

6. Irman, I.J., Efendy Supli., Garnida, Yudi., (2002). Pengaruh Penambahan Ragi Kecap, Ragi Tempe, Non Ragi dan Lama Proses Penggaraman Kacang Kedelai Hitam terhadap Mutu Kecap Manis. FT Universitas Pasundan, Bandung.

7. Kartika, B. Dkk. (1988). Pedoman Uji Inderawi Bahan Pangan. Universitas Gajah Mada. Yogyakarta.

8. Nurul, Sofyan Iyan, Sumartini. (2012). Pengaruh Konsentrasi Bacillus subtillis Natto dan Suhu Fermentasi terhadap Karakteristik Natto Kacang Koro Pedang. Tugas Akhir Jurusan Teknologi Pangan Fakultas Teknik Universitas Pasundan, Bandung.

9. Rianty, H., Taufik, Y., Garnida, Y. (2014). Optimalisasi Formulasi Kecap Kacang Koro Pedang dengan Design Expert metode DOptimal. Tugas Akhir Jurusan Teknologi Pangan Universitas Pasundan Bandung.

10. Sarwono B., dkk (2005). Membuat Tempe dab Oncom. Penebar Swadaya, Jakarta.

11. Sayuti. (2015). Pengaruh Bahan Kemasan dan Lama Inkubasi terhadap Kualitas Tempe Kacang Gude. Bioedukasi UMM. Lampung.

12. Standar Nasional Indonesia (SNI). (1994). Syarat Mutu Kecap Kedelai.

13. Standar Nasional Indonesia (SNI). (1999). Standar Nasional Indonesia Kecap Kedelai.

14. Turyoni, D. (2007). Pengaruh Penambahan Gula Kelapa Terhadap Kualitas Dodol Tanpa Kulit Singkong (Casava). Jurnal FT Semarang, Semarang.

15. Winarno, F. G. (1992). Kimia Pangan. Penerbit PT Gramedia Pustaka Utama. Jakarta.

16. Yohana, M. (2011). Pemanfaatan Ampas Tahu sebagai Bahan Baku Pembuatan Kecap Manis dengan Penambahan Tepung Beras. Skripsi FTIP IPB. Bogor.

17. Yuanita, I. (2013). Analisis Kualitas Pembuatan Kecap Asin Ampas Tahu Dengan Kajian Jumlah Ampas Tahu Dan Kacang Koro Benguk (Mucuna pruriens). Fakultas Teknologi Pertanian, Universitas Brawijaya, Malang. 